\title{
CASGER: CASING YANG BERFUNGSI SEBAGAI CHARGER DARURAT
}

\author{
Rony Aldhea Dwi Cahya \\ Fakultas Teknik, Teknik Elektro \\ Universitas Negeri Malang \\ Email: radc.boy@gmail.com \\ Rendra Kurniawan \\ Fakultas Teknik, Teknik Elektro \\ Universitas Negeri Malang \\ Adam Abi Nugroho \\ Fakultas Teknik, Teknik Elektro \\ Universitas Negeri Malang \\ Muhamad Arifin \\ Pascasarjana, Pendidikan Kejuruan \\ Universitas Negeri Malang
}

\begin{abstract}
ABSTRAK
Telah dilakukan pembuatan projek Casger, yakni sebuah prototipe casing yang berfungsi sebagai charger untuk ponsel. Casger yang telah dibuat ini memiliki prinsip kerja yaitu ketika dilakukan remasan tangan maka akan menggerakkan generator sehingga generator bisa menghasilkan sumber listrik untuk mengisi daya baterai handphone. Remasan tangan pada casger dihasilkan dari tuas yang berada pada samping casing, apabila ditekan akan memicu gear pemicu putaran yang akan menggerakkan gear dinamo, kemudian energi listrik dari putaran akan masuk di penyearah arus dan DC-DC conventer, tegangan akan dinaikkan menjadi 4 volt yang kemudian disimpan dalam baterai, dan untuk penghentian pengisian charger dilengkapi saklar on/off untuk pemutus arus listrik. Hasil dari pengembangan prototype Casger yang telah dihasilkan diantaranya 1) casing juga sebagai charger handphone; 2) jumlah pemompaan sebanyak 25 kali akan menghasilkan arus $800 \mathrm{mAh}$; 3) tegangan total 4 volt masuk ke baterai penyimpanan; dan 4) baterai penyimpanan ke handphone dapat dihitung dari daya maksimal penyimpanan/kebutuhan arus dari handphone. Perlu lebih dari 150 kali pompaan untuk menghasilkan arus yang dapat disimpan di baterai penyimpanan dengan kapasitas arus $>5000 \mathrm{mAh}$
\end{abstract}

Kata Kunci: energi alternatif, energi kinetik, casger.

\begin{abstract}
Have been fabricated Casger project, which is a prototype chasing with serves as a charger for mobile phones. Casger who have made this has a working principle of the squeeze of the hand when it is done it will drive a generator so that the generator can produce a power source to charge the phone battery. Squeeze hand of Casger resulting from the lever which are on the side of the casing, when pressed will trigger a round trigger gear that will drive the dynamo gear, then the electrical energy of the round will be entered in the current rectifier and DC-DC conventer, the voltage will be increased to 4 volts which is then stored in batteries, and for termination of charging charger be equipped on/off switch for the electric current breaker. Results of Casger prototype development that has produced such: 1) the casing as well as a mobile phone charger, 2) the amount of pumping as much as 25 times will produce a flow of $800 \mathrm{mAh}$, 3) the total voltage of 4 volts into the storage battery and, 4) the storage battery to the phone can be calculated from the maximum power storage / current needs of the mobile phone. Need more than 150 times the pumping to generate a current that can be stored in the storage battery with a current capacity of $>5000 \mathrm{mAh}$.
\end{abstract}

Keywords: alternative energy, kinetic energy, casger. 


\section{PENDAHULUAN}

Salah satu alat teknologi yang tidak lepas dari kehidupan masyarakat adalah handphone. Dulu handphone hanya bisa menjadi alat komunikasi saja semisal alat untuk telepon, sms, dan radio. Kini handphone telah berevolusi menjadi tidak hanya alat komunikasi saja, tetapi juga alat yang mampu menjalankan sebagian kemampuan kerja dari komputer sekalipun. Sehingga tidak heran sekarang ini telah berubah trend dari handphone menjadi smartphone, yaitu handphone yang memiliki kemampuan menggantikan sebagian kinerja dari komputer [7].

Namun konsekuensi dari semakin canggihnya alat teknologi yaitu kebutuhan daya yang juga semakin tinggi. Teknologi sekarang ini telah berkembang menjadi alat-alat portable, yaitu alat yang tidak perlu dihubungkan langsung ke sumber utama arus listrik tetapi memakai daya yang disimpan di dalam baterai. Dengan semakin besar kapasitas yang dimiliki baterai maka semakin lama handphone bisa bertahan. Namun konsekuensi alat portable jika daya di dalam baterai telah habis maka daya harus diisi ulang [4]. Pengisian daya membutuhkan sumber arus listrik yang bisa mengisi daya pada baterai. Namun jika tidak bisa menemukan sumber arus listrik maka daya tidak dapat diisi ulang.

Berdasarkan kuesioner yang disebarkan di lingkungan Universitas Negeri Malang, dari 100 kuesioner 72 responden berpendapat bahwa mereka sering kehabisan daya baterai di saat yang diperlukan. Sehingga, dengan kondisi handphone yang portable maka diperlukan adanya suatu teknologi yang dapat mengisi daya pada baterai untuk keperluan sewaktu-waktu. Sekarang sedang berkembang teknologi power bank, yaitu alat yang dapat menyimpan daya listrik dan bisa dibawa kemanapun dan dapat digunakan sewaktu-waktu ketika daya pada handphone habis.

Namun kekurangan dari alat ini adalah jika daya pada power bank habis maka tidak bisa mengisi daya pada gadget dan power bank harus diisi ulang. Oleh karena itu power bank tidak praktis karena bergantung juga pada kapasitas dan tidak bisa menghasilkan daya tambahan secara mandiri. Oleh karena itu diperlukan alat yang bisa mengisi daya pada handphone tanpa bergantung pada kapasitas sehingga bisa digunakan sewaktu-waktu. Alat tersebut harus bisa menghasilkan tenaga listrik sebagai untuk membangkitkan daya listrik.

Salah satu tenaga yang bisa dimanfaatkan adalah remasan tangan (energi kinetik). Remasan tangan bisa menggerakan generator yang telah dipasang pada alat sehingga generator bisa menghasilkan sumber listrik untuk mengisi daya handphone [3]. Menurut Wiyanto, dalam bukunya "Elektromagnetika", perubahan medan magnet akan menimbulkan arus listrik yang arahnya sedemikian sehingga medan magnet yang dihasilkan oleh arus itu akan melawan perubahan medan magnet yang menimbulkan arus tersebut. Perubahan medan magnet menurut hukum faraday akan menimbulkan medan listrik yang ditunjukkan oleh adanya arus listrik yang mengalir pada loop, yaitu fluks yang melewati loop itu semakin besar [8].

Penelitian yang pernah dilakukan dengan memanfaatkan energi kinetik yakni pengembangan produk trekking pole sebagai alat penghasil cadangan energi listrik pada kegiatan hiking, pemanfaatan energi kinetik yang dilakukan pada tingkat pergerakan yang tinggi. Energi listrik yang dihimpun digunakan untuk peralatan lainnya yang rata-rata membutuhkan energi listrik yang tidak terlalu besar [2].

Namun walaupun sangat dibutuhkan, pembangkit listrik portable tersebut harus tidak membuat tampilan peralatan handphone menjadi jelek sehingga perlu pengemasan charger yang baik. Salah satu cara pengemasannya adalah dengan mengintegrasikan charger portable tersebut sebagai casing peralatan mobile sehingga bisa menjadi alat untuk mempercantik tampilan handphone sekaligus pengisi daya handphone.

\section{METODE PELAKSANAAN}

\subsection{Blok Diagram Perencanaan Alat}

Proses sistem kerja dari Casger dijelaskan pada Gambar 1 diagram blok berikut.

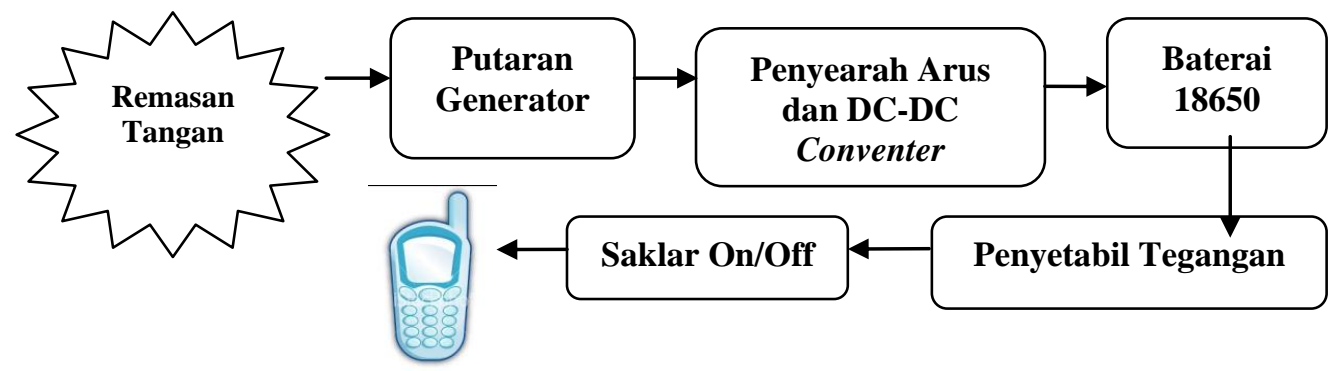

Gambar 1. Diagram Blok Sistem Casger 
Berdasarkan Gambar 1 penjelasan dari fungsi masing-masing diagram blok adalah sebagai berikut:

1. Energi kinetik remasan tangan sebagai sumber utama energi,

2. Putaran generator sebagai pengubah penggerak energi untuk menjadi energi listrik,

3. Penyearah arus dan DC-DC conventer, penyearah arus sebagai pengubah arus AC menjadi DC, DC-DC conventer untuk meningkatkan tegangan antara 0,9 volt sampai 4 volt [1].

4. Baterai sebagai penyimpan energi listrik yang dihasilkan oleh remasan tangan.

5. Penstabil tegangan untuk mempertahankan tegangan dari baterai 4 Volt supaya bisa masuk ke baterai handphone sebesar 4 Volt.

6. Saklar on/off sebagai penyambung dan pemutus aliran listrik. Digunakan saat pengisian baterai digunakan atau tidak.

\subsection{Desain Alat}

Berikut ini merupakan gambar desain Casger sesuai dengan pengembangan yang akan dilakukan. Lihat Gambar 2 dan Gambar 3 berikut.
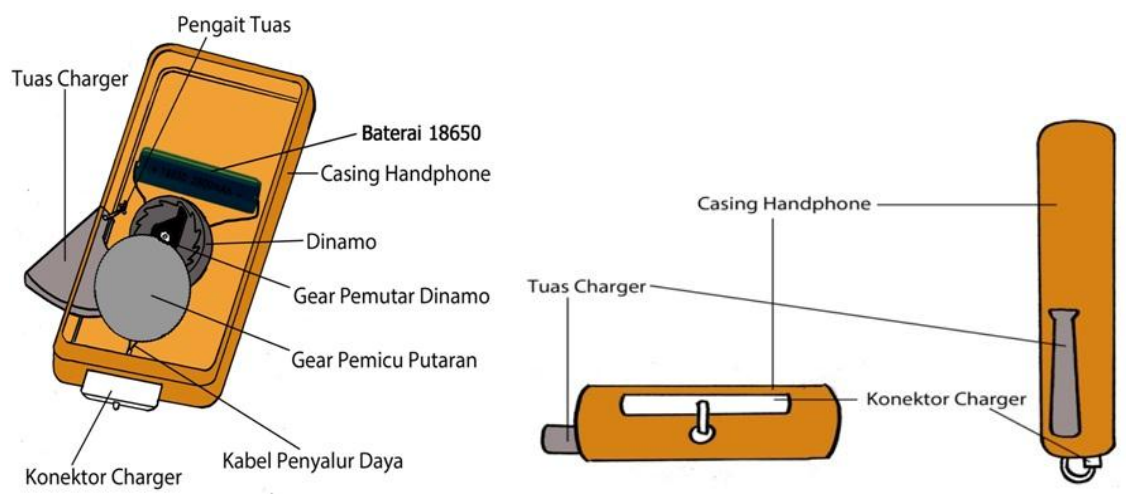

Gambar 2. Desain Casger 2 Dimensi Tampak Depan dan Samping
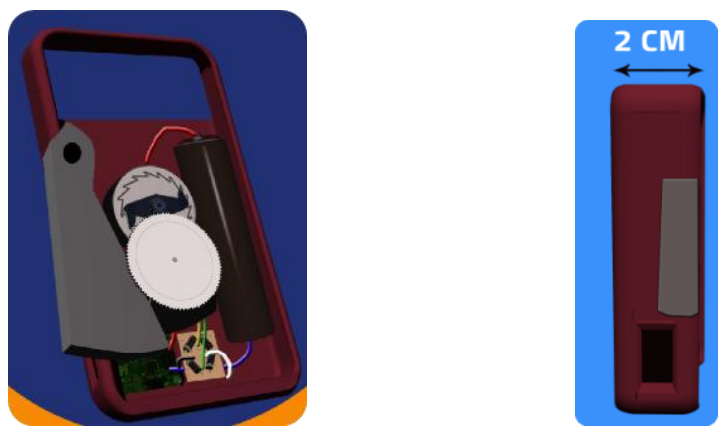

\section{Gambar 3. Desain Casger 3 Dimensi Tampak Depan dan Samping}

\subsection{Waktu dan Tempat Pelaksanaan}

Kegiatan ini dilaksanakan dari akhir bulan maret sampai dengan bulan mei tahun 2014. Tempat pelaksanaan kegiatan tempat kontrakan masing-masing anggota dan Labolatorium Elektronika, Jurusan Teknik Elektro, Fakultas Teknik Universitas Negeri Malang (UM).

\subsection{Komponen yang Dibutuhkan}

Komponen yang digunakan pada kegiatan ini adalah sebagai berikut:

a) Solder

b) Penyedot timah

c) Multimeter

d) Bor dan mata bor 

e) Cutter
f) Gunting
g) Lem tembak
h) Tuas
i) Baterai
j) Casing handphone
k) Baterai 18650
1) Dinamo
m) Gear
n) Buck converter dan USB

\section{HASIL DAN PEMBAHASAN}

Teknologi Casger yakni integrasi antara casing dan charger yang digunakan dalam perangkat handphone. Teknologi ini memanfaatkan remasan tangan untuk memutar generator sehingga menghasilkan arus listrik. Arus listrik yang dihasilkan disimpan dalam baterai isi ulang (3 volt) yang ada pada Casger. Casger dapat digunakan sewaktu baterai dalam keadaan full (untuk pemakaian lama dengan nyala lampu LED stabil) dengan mengatur saklar pada Casger atau dalam keadaan baterai kosong dengan memompa secara berkala Gasger tersebut.

Komponen gear ini tersusun dari 3 gear, 2 gear yang terpasang menyatu $(\mathrm{d}=4 \mathrm{~cm}$ dan $\mathrm{d}=0.8 \mathrm{~cm})$ untuk menghubungkan putaran dari remasan atau tekanan tuas charger dan memutar magnet disekitar kumparan tembaga. Gear yang lainnya $(\mathrm{d}=0.8 \mathrm{~cm})$ terpasang menyatu dengan magnet supaya magnet dapat berotasi. Rumus Menghitung putaran gear kecil dan besar

Putaran $=\pi . D$

$\boldsymbol{\pi}=$ Konstanta rumus lingkaran $(3.14 / 22 / 7)$

$\mathbf{D}=$ diameter lingkaran $(\mathrm{cm})$

Arus listrik AC yang dihasilkan Gasger diubah menjadi arus listrik DC dengan menggunakan komponen dioda jenis IN 4002. Selanjutnya arus dari dioda akan dialirkan menuju baterai tipe 18650 dengan tegangan 3.7 volt sebagai sumber tegangan. Sumber tegangan dihubungkan dengan kabel connector ke handphone yang dihubungkan oleh saklar sebagai pengatur untuk bisa digunakan langsung dalam proses charging handphone. Rumus Menghitung Keliling gear kecil dan besar

\section{Keliling $=\boldsymbol{\pi} . \mathbf{D}$}

$\boldsymbol{\pi}=$ Konstanta rumus lingkaran $(3.14 / 22 / 7)$

$\mathbf{D}=$ diameter lingkaran $(\mathrm{cm})$

Rumus Menghitung putaran gear kecil dengan bantuan gear besar (P1)

P1 = Keliling gear besar

$\overline{\text { Keliling gear kecil }}$

Tabel 1. Hasil Pengukuran Arus dan Tegangan yang dihasilkan Generator

\begin{tabular}{lccc}
\hline \multicolumn{1}{c}{ Perlakuan } & Arus & Tegangan & Daya \\
\hline Pemompaan minimal & $8 \mathrm{~mA}$ & $1 \mathrm{~V}$ & 0.008 Watt \\
\hline Pemompaan maksimal & $48 \mathrm{~mA}$ & $3 \mathrm{~V}$ & 0.144 Watt \\
\hline Pemompaan Rata-rata & $32 \mathrm{~mA}$ & $2 \mathrm{~V}$ & 0.064 Watt \\
\hline Pemompaan berulang-ulang & $24 \mathrm{~mA}$ & $1.2 \mathrm{~V}$ & 0.0288 Watt \\
\hline
\end{tabular}

Keterangan:

a) Perlakuan Casger dilakukan dengan sekali pompa ,lalu dilepas dan begitu seterusnya. Jika dalam perhitungan putaran gear, gear yang memutar generator berotasi sebanyak 5 kali.

Satu kali putaran gear besar $(\mathrm{d}=4 \mathrm{~cm})$

Keliling $=\boldsymbol{\pi} . \mathbf{D}$

$$
\begin{aligned}
& =3.14 \times 4 \mathrm{~cm} \\
& =12.56 \mathrm{~cm}
\end{aligned}
$$

Satu kali putaran gear kecil $(\mathrm{d}=0.8 \mathrm{~cm})$ 
Keliling $=\boldsymbol{\pi} \cdot \mathbf{D}$

Keliling $=3.14 \times 0.8 \mathrm{~cm}$

$$
=2.512 \mathrm{~cm}
$$

Hasil putaran gear kecil dengan bantuan gear besar (P1)

$$
\begin{aligned}
\mathrm{P} 1 & =\frac{\text { Keliling gear } \text { besar }}{\text { Keliling gear kecil }} \\
& =\frac{12.56 \mathrm{~cm}}{2.512 \mathrm{~cm}} \\
& =5 \text { kali putaran }
\end{aligned}
$$

b) Pemompaan rata-rata artinya pemompaan yang dilakukan dengan tenaga maksimal atau minimal tanpa memerhatikan indikator maksimal atau minimal.

Analisis:

Hasil dari percobaan pengukuran arus dan tegangan yang dihasilkan putaran generator menggunakan AVO meter analog, perlakuan pemompaan maksimal dengan sekali pompa memberi hasil tertinggi pada arus dan tegangan, sedangkan perlakuan pemompaan minimal dengan sekali pompa memberi hasil terendah pada arus dan tegangan. Perlakukan pemompaan rata-rata memberikan hasil yang berada ditengah-tengah pemompaan minimal dan maksimal di arus dan tegangan. Hal ini disebabkan karena rata-rata manusia menekan atau memompa tuas tidak selalu stabil, kadang menghasilkan hasil maksimal atau minimal.

Jika dibandingkan dengan perlakuan pemompaan berulang-ulang, pemompaan rata-rata dengan sekali pompa lebih besar hasilnya di arus dan tegangan. Sehingga peneliti menggunakan acuan hasil pemompaan rata-rata untuk diujicobakan ke rangkaian.

Tabel 2. Hasil Pengukuran Arus dan Tegangan yang dihasilkan Generator

\begin{tabular}{cccc}
\hline Arus Awal & Arus Akhir & Tegangan Awal & Tegangan Akhir \\
\hline $750 \mathrm{~mA}$ & $750 \mathrm{~mA}$ & $1,8 \mathrm{~V}$ & $3,5 \mathrm{~V}$ \\
\hline $800 \mathrm{~mA}$ & $800 \mathrm{~mA}$ & $2 \mathrm{~V}$ & $4 \mathrm{~V}$ \\
\hline
\end{tabular}

Keterangan:
a) Perlakuan Casger yang dilakukan adalah pemompaan rata-rata sebanyak 25 kali pompaan
b) Rangkaian yang digunakan yaitu rangkaian dioda jembatan bridge
c) Menggunakan modul DC-DC converter untuk meningkatkan tegangan
d) Arus awal adalah arus yang dihasilkan sebelum melewati $D C-D C$ converter
e) Arus Akhir adalah arus yang dihasilkan setelah melewati $D C-D C$ converter
f) Tegangan awal adalah arus yang dihasilkan sebelum melewati $D C-D C$ converter
g) Arus Akhir adalah arus yang dihasilkan setelah melewati $D C-D C$ converter

Analisis

Hasil percobaan pertama kami gunakan untuk mengukur arus dan tegangan yang dihasilkan dari Casger ke rangkaian sebagai arus dan tegangan awal. Arus dari Casger yang telah disearahkan melalui rangkaian dioda jembatan bridge dan modul DC-DC converter, menghasilkan arus akhir yang tetap seperti arus semula. Sedangkan tegangan akhir yang dihasilkan meningkat 2 kali lipat dari tegangan semula menjadi 4 Volt. Untuk charger ponsel sebagai pengisi arus pada baterai, merupakan hal yang tak terpisahkan dari handphone. Umumnya mempunyai tegangan 4,56 V untuk semua handphone [5].

\section{Bentuk Prototype yang Dikembangkan}

Bentuk prototype yang dikembangkan melalui proses studi lapangan, survei dan desain rancangan awal. Bentuk dan sistem kinetic energy dari desain akhir ini merupakan pengembangan lanjutan dari alternatif desain awal, lihat Gambar 4 dan 5. 


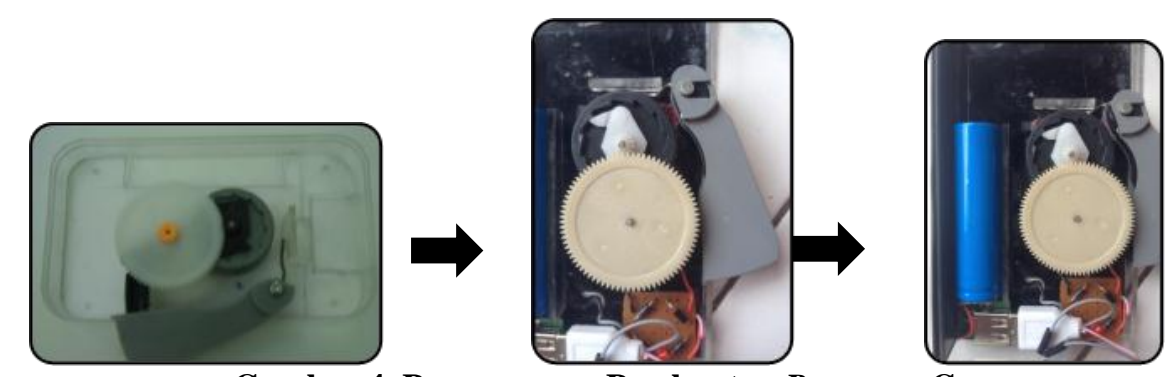

Gambar 4. Perancangan Pembuatan Prototype Casger
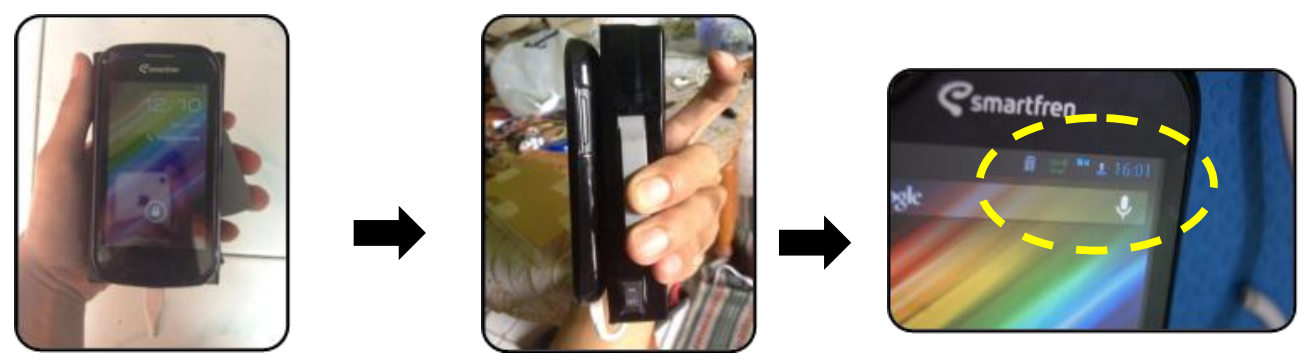

Gambar 5. Pengujian Prototype Casger

\section{KESIMPULAN}

Berdasarkan hasil dan pembahasan, maka kesimpulan dari pembuatan alat ini sebagai berikut:

1. Pembuatan projek ini harus memperhitungkan: jumlah pemakaian dan daya pada powerbank dari remasan tangan.

2. Rancangan Casger yang besar dan masih berupa prototype, karena menyesuaikan dengan ukuran handphone.

3. Spesifikasi Casger yang telah tim rancang sebagai berikut: (1) casing juga sebagai charger handphone, (2) jumlah pemompaan sebanyak 25 kali akan menghasilkan arus $800 \mathrm{mAh}$, (3) Tegangan total 4 Volt masuk ke baterai penyimpanan, dan (4) baterai penyimpanan ke handphone dapat dihitung dari daya maksimal penyimpanan/kebutuhan arus dari handphone. Perlu lebih dari 150 kali pompaan untuk menghasilkan arus yang dapat disimpan di baterai penyimpanan dengan kapasitas arus $>5000 \mathrm{mAh}$.

\section{DAFTAR PUSTAKA}

[1] Blocher, Richard. 2003."Dasar Elektronika".Yogyakarta: Penerbit Andi.

[2] Bilardi A, Ryan. 2014. "Pengembangan Produk Trekking Pole sebagai Alat Penghasil Cadangan Energi Listrik pada Kegiatan Hiking". Jurnal Tingkat Sarjana Seni Rupa dan Desain Vol 1: Bandung: Program Studi Sarjana Desain Produk, Fakultas Seni Rupa dan Desain (FSRD) ITB.

[3] Chesire, Gerard. 2008. "Electricity and Magnetism". Solo: Tiga Serangkai.

[4] Donnel, Henri. 2005. "Kupas Tuntas Hardware Handphone”. Semarang: Penerbit Vyctoria.

[5] M.H, Zaki. 2005. “Cara Mudah Belajar Merangkai Elektronika Dasar”.Yogyakarta: Absolut.

[6] Marsudi, Djiteng. 2011. "Pembangkitan Energi Listrik Edisi Kedua". Jakarta: Erlangga.

[7] Mulyanta, Edi. 2003. "Kupas Tuntas Telepon Selular Anda".Yogyakarta:Penerbit Andi.

[8] Wiyanto. 2008. "Elektromagnetika”. Yogyakarta: Graha Ilmu.

[9] Rizqy, Hidayat. 2007. "Mengenal Jenis Battery Handphone" (Online) http://dehagoblog.wordpress.com/2007/10/25/mengenal-jenis-battery-handphone, diakses pada tanggal 8 Desember 2014. 